\title{
パナマ運河の計画とその技術の变遷について
}

運翰省港潑技術研究所 $\begin{array}{ll}\text { 正会員 } & \text { 長 野 正 孝 } \\ \text { 正会員 } & \text { 山本焂司 }\end{array}$

中米地侠運河は、16世紀からその必要性が叫ばれていたが、20世紀初頭になって、

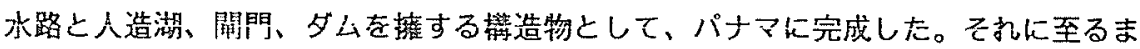
で、技術の進歩と計画規模の增大という相亮の歴史があった。

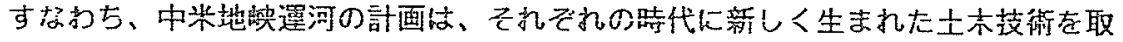
り入れながら、より優れたものになってきたが、一方では、この200年間に船舶が悆

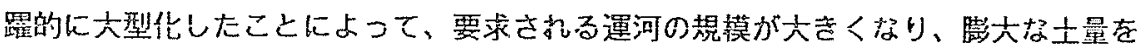
掘削し、巨大な閘門を建設することを余域なくさせられてきた。本諭では、その歴史 について、技竹面に焦点をあてて、以下の点について、分析、詝価を行つた。

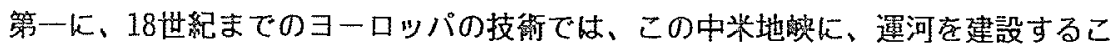
とは不可能であったことを畿つかの角度から傍証した。

第二に、レセップスの時代には、技衔的な制約はほぼ解渗し、中米地傸運河は、パ ナマにおいて、その㚘䉂は別にして、可能となっていたことを傍証した。すなすち、

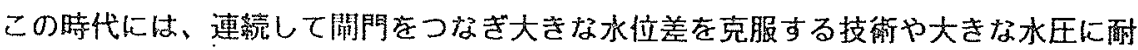

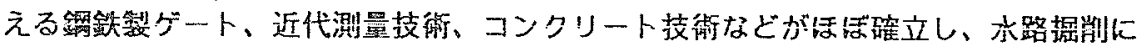
不可欠な㩧削機荹、浚㴖船、ダイナマイトなども登場した。

第三に、何故、近代㖶河に鏍欽製ゲートが必要となってきたかについて分数した。 すなわち、伝統的なヨーロッパの關門式運河では、その水位差が5mになると限界に達 するという経駼則があったが、本諭では、その原因の一つがゲートの材質に亦ること を明らかにし、中米地侠運河実現のためには銅銠製ゲートが必要であったことを傍証 した。

第四に、閘門をコンクリート㝤造にすることによって、大型の閘門と給水用のダム が可能になったことも明らかにした。すなるち、19世紀末からフランスとアメリカに よって行われた現パナマ運河のプロトタイプの計画から、重力式コンクリート構造が 不可欠となった背景とその技采亦準を分析した。

第五に、パナマ運河の最近の計画と掘削土量の变遷について評価し、将来の運河の あり方を示唆した。

[パナマ運河、關門、掘削土量、中世〜䍐代 $]$ 
はじめに

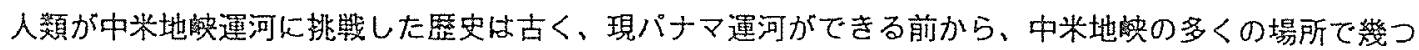

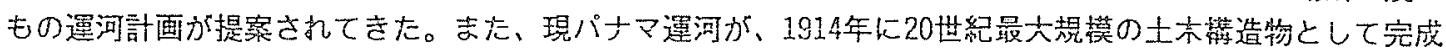
してからも、閘門式蒾河故の制約などから、新しい運河計画が、今日まで幾度も提案されてきている。

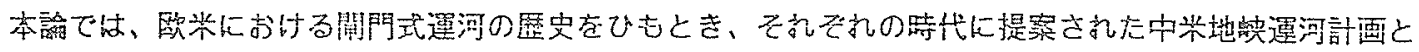

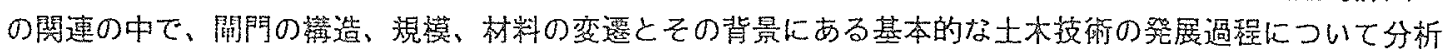

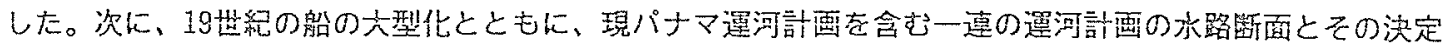

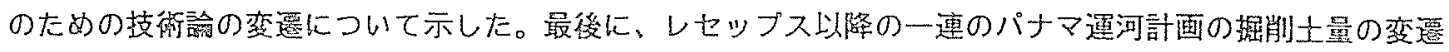

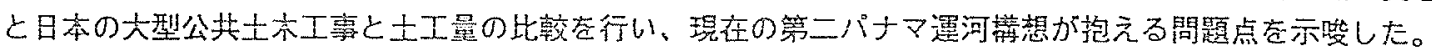

我が国は、交通实上、欧柴のように、㖶河が脚光を浴びた時代を経ておらず、㖶河や水路翰送の研究は数

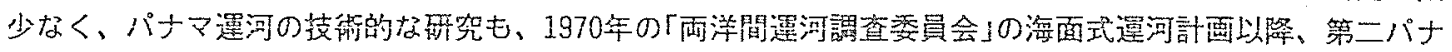
マ運河の施工技㫱に関する研究や、その桨来需要に関する研究が行われているたりである。パナマ運河とい

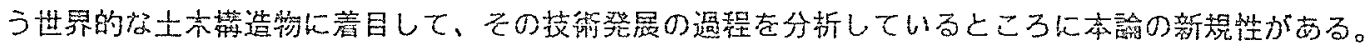

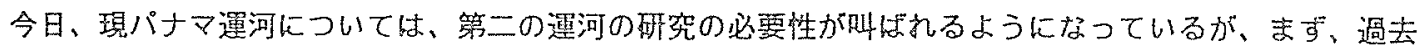

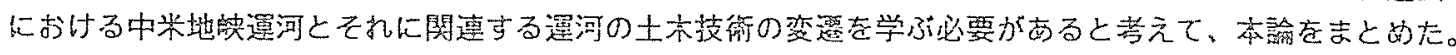
なぜならば、将亲、第二パナマ運河で、技街者が铞討を必要とするであろう基本的な問題点の多くは、すで に先人が㙰決してきているからである。

\section{1. 閭閏式遷河のルーツ}

中米地踳㞄河の必要性怄、メキシコを征服したコルテス(Hernando Cortez)によって、1524年に初めて提

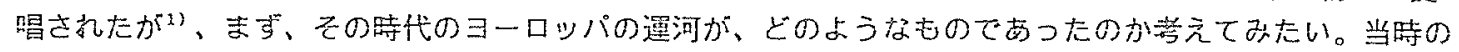
ヨーロッパでは海面(水平)式と閘門式運河という2つの運河の概念がすでに存在していた。

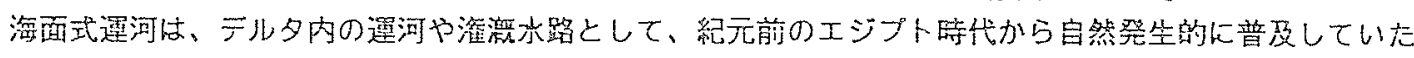

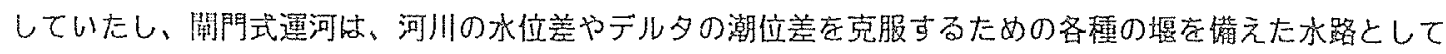

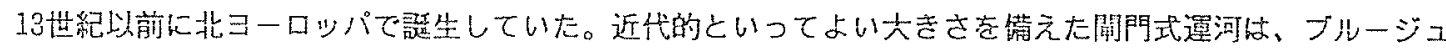
(Brugge)㞄河やシュテックニッッ(Stechnitsz)邁河が最初であるとされ、14世紀のことであった

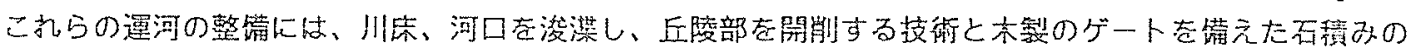
閘門を造る技郝が必要であった。

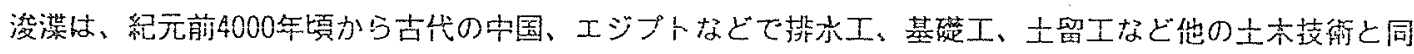

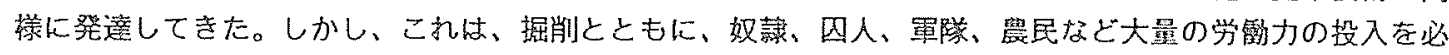

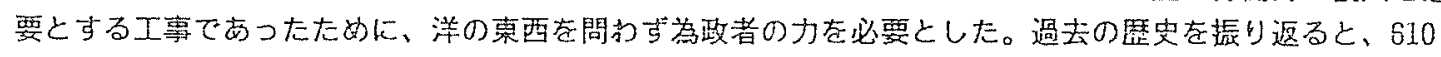
年に隋の婸帝が完成させた長江河口の机州と天津を結んだ大邁河では200万人が、17世紀のフランスのブリ

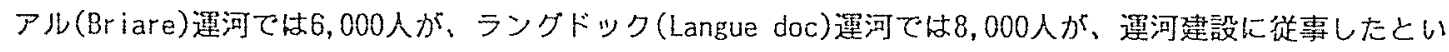
う記録が残っている41.5)。

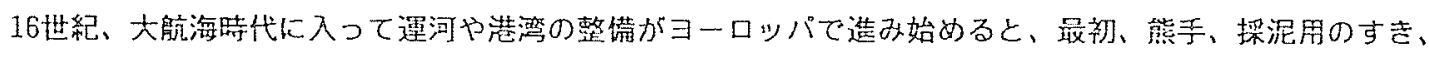
グラブなどが普及し始めた。やがて、16世紀末になると、マッドミルと呼ばれる車翰式の大きな人力浚溧装 䈯が誔生し、ヨーロッパに监及していっだ)。

水位差を克服する本製ゲートについては、17の简単な塸迄めを持ったシュテックニッッ運河が1398年にで

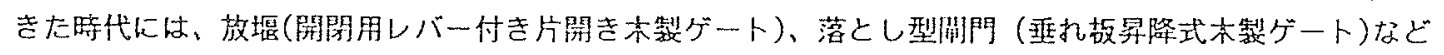
様々な形の塸や水門がヨーロッパに存在していたが2)、やがて、15世紀にパナマ運河のゲートと同じタイプ の篗音開きのマイターゲートが、イタリアで誔生し、ヨーロッパの主要運河に普及していつた。1450年垻、 イタリアの建築家アルベルチ(Leon Battista Alberti)がその概念を唱えたこと、1497年にレオナルド・ダ． 
ヴィンチ(Leonardo da Vinci)がミラノ(Milano)運河で实祭に設計、施エしたことが、マイターゲートの起原 とされている21，6)，7)。コロンブスが新大陸を発見した頃であった。

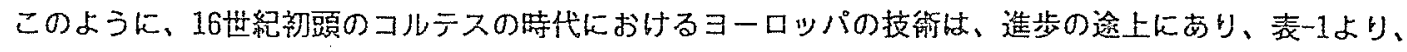
長さ $30 \mathrm{~m}$ 、湢 $10 \mathrm{~m}$ 前後、水梁1 2mの小さい關門の建設を可能とし、平野部の勾配のゆるやかな水路で小さな

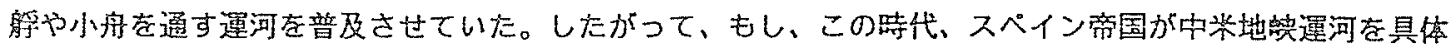
的に检討していたならば、この程度のものであったろうと推論できる。

表一1１4〜17世紀初頭のヨーロッパの主な内陸運河の記録

\begin{tabular}{|c|c|c|c|}
\hline 完成時期 & 水路名 & 場 所. 特 徵 & 規 \\
\hline $1394 \sim 96$ & 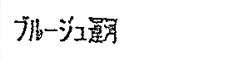 & 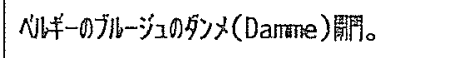 & 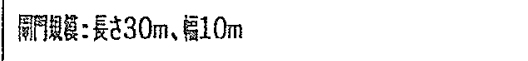 \\
\hline $1391 \sim 98$ & 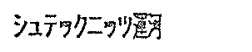 & 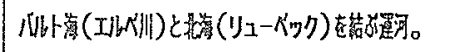 & 解:長さ10m、㥰3.3m \\
\hline $1438 \sim 39$ & らィриノ(Viarenno) & 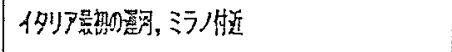 & \\
\hline $1482 \sim ?$ & 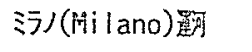 & 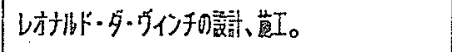 & 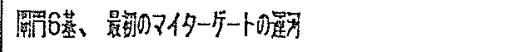 \\
\hline \multicolumn{4}{|c|}{1524 コルテス中类地焕運河提唱 } \\
\hline 1548 & 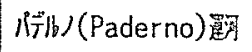 & 例ア代长表影。 & 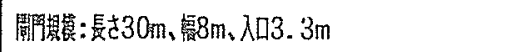 \\
\hline $1605 \sim 42$ & フำル露通 & 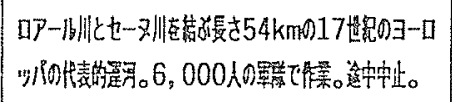 & 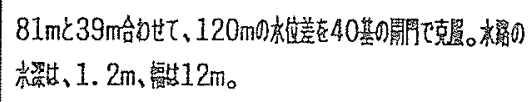 \\
\hline 1682 92 & 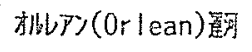 & 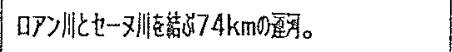 & 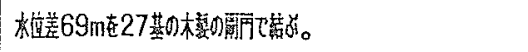 \\
\hline $1666 \sim 92$ & 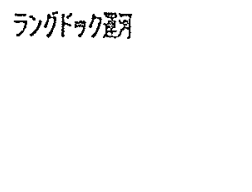 & 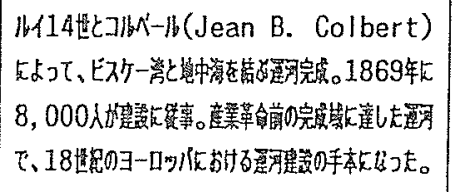 & 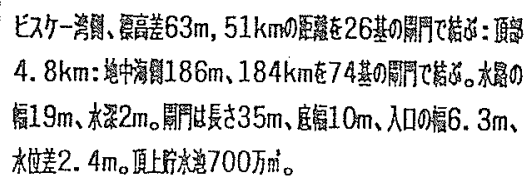 \\
\hline
\end{tabular}

2. 近世運河の発達と中米地陕運河の挑戦

出典 : 2), 3), 4),7)

座業革命とともに、最初にイギリスで河川舟要が発遧し、䦌門式運河が普及していつた。イギリスにおけ る近代運河の隄垁は、1761年に完成したワースリー(Worsley)炭坑からマンチェスターを結ぶブリッジウオ 一ター(Bridgewater)邁河である。やがて、1830年までにイングランドとウェールズに、3,101kmの量河と2,1 $11 \mathrm{~km}$ 改修河川が完成した。国土横断運河として、ケネット(Kennett)川とエーボン(Avon)間、セヴァーン (Severn)川とテムズ川間の運河、カレドニア(Caledonian)運河などができた ${ }^{3) .81 .9) 。 ~}$

フランスでは、ナポレオン戦争で産業革命が㩧れ、整備された運河は1830年まで総延長 $900 \mathrm{~km}$ に過ぎな

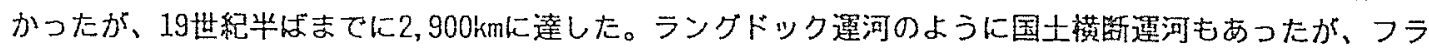


ンスでは、主としてセーヌ川流域以北で発展した。現在、4,700kmの㖶河が利男されている31.81.101.

ドイツでは、19世紀前半までにライン、オーテル、エルベ、ドナウの各水系を結ぶ運河網が完成した。有 名なもので、ライン川とエルベ川を結ぶミッドランド(Midlands)運河、ライン川とドナウ川を結ぶレーゲニ ッッ(Regenitz)運河がある。現在、7、000kmの運河が利用されている3111)。イタリアでは、パテルノ (Paderno)運河か1777年に完成し、平野部の多い北部で発晨した。北欧では1770年代から、デンマーク人に よって北海とバルト海を結ぶ運河が造られ始め、スウェーデンでは、1832年、国土横断運河として、エータ (Gota)㖶河が完成した。この㖶河は首都ストックホルムからエーテボリまでの川や湖を結んだ。31，8)、123

アメリカでは、17世紀末から五大湖や北部の河川を中心に、多くの計画が提案されたが、実際に建設が始

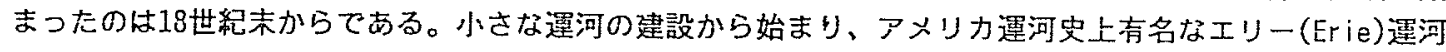
の建設が1825年に行なわれた。この運河の完成によって、ニューヨークと五大湖地方が結ばれ、ニューヨー クの発展を支えることになつた ${ }^{3)}$ (8)。

このように、欧米の運河は、鉄道 や道路翰送絧が発橽する前に、内陸 翰送の手段として、ヨーロッパやア メリカ東部を中心に発達したが、そ の背景には、河口部の低湿地帯など では、鉄道や道路整備に比べて、技 街がそれ程苇しくなかったこともあ る。しかし、これらの運河は、基本 的に中世のものと变わるとこうが無 く、閘門も低落差の小さな艀や小舟 を通すだけのものであった。

たとえば、ケネット川では、水位 差 $41 \mathrm{~m}$ を長さ $37 \mathrm{~m} 、$ 䒇5.7mの閘門 18 基 で克服していだ”。

19世紀にはウェランド(Welland) 運河やスエズ浢河、マンチェスター 運河、キール運河のような外洋船を

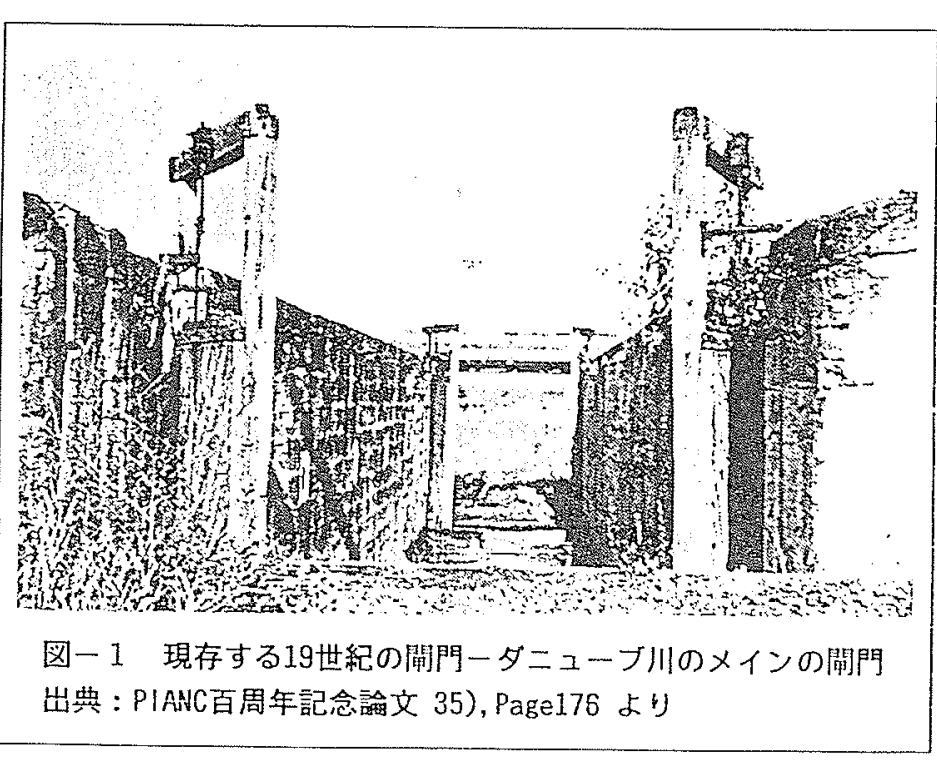
図ー1＼cjkstart現存する19世紀の閘門ーダニューブ川のメインの閘門 出典 : PIANC百周年記念諭文 35), Page176 より

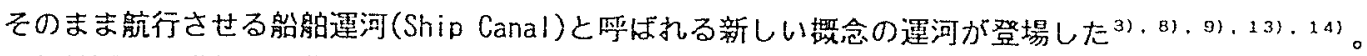

船舶運河の夢矢圤、北部スコットランドの国土横断運河として1822年(1847年完成)に開通したカレドニア 運河とカナダのセントローレンス水路に1829年に完成したウェランド運河といわれている。前者は、木製と

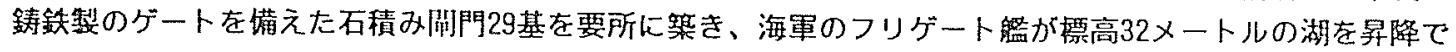

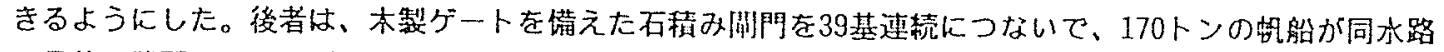
の琶後の難関のナイアガラ滝の100mの大落差を昇降できるようにした ${ }^{91.131 .15) 。 ~}$

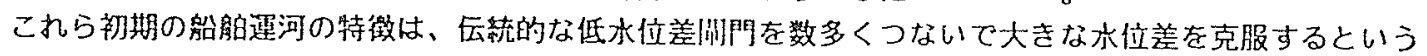
ことにあった。このアイテアは、中米地蝧のような標高差のある運河に萝を与えた。すなわち、表一的示す ように、フランス政府陵員ガレラ(N. Garella)のパナマ遇河(1838計画:35阙門)やアメリカ軍人チャイルス

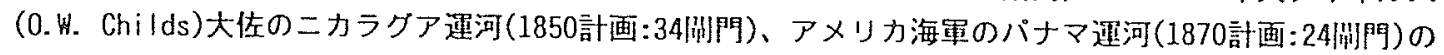
ように䦌門の段数が多い運河蚻想が、19世紀中䪸にブームとなったのである ${ }^{16) 。 ~}$

その技衔の鍵は、数百人の石工によって多数の同じサイズの湴門を造ること、漏水と沈下を防止する工夫

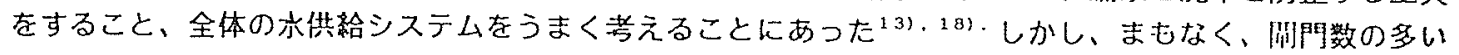
運河は、維持管理費と通航時間が卦かることが分かり、このアイデアは時代䐅扎なものとなった ${ }^{18) 。 ~}$ 
大きな虮新、蒸気新の出現仙、一つ で大きな水位差を克服する福の広い大 型閘門を必要とするようになった。层 統的な低落差の關門から鎡鉄製のゲー トを持った大落差のコンクリート製關 門に技術移っていった。

ウェランド運河は技術発展の歴史の 証人であり、その舞、図-2に示す占う に、1845年、1887年、1933年と 3 回に わたってカナダ政府によって㹡諨、增 強され、銅鉄製のゲートを诺えたコン クリート製閘門に生まれ变わり、8基 という少ない閘門で100mの大きな水位 善を克服している ${ }^{13)}$ 。

3. パナマ運河を実現させた技制

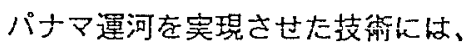
ダイナマイトの発明、浚渫船の進歩な どが特筆できるが、ここでは、中米地 䁚量技街の閔係、ゲートの材質問 題、初期のコンクリート構造設計技術 について俨価を試みた。

\section{（1）浿量技街の進歩}

中米地蛦は、 $2,800 \mathrm{~km}$ あり、地形が 䄍雜に入り組み、人跡未踏のジャング ルに覆われていたために、測量調查は 捗らず、パナマ運河に緵られるまで、 3世紀以上の歲月が掛かった。

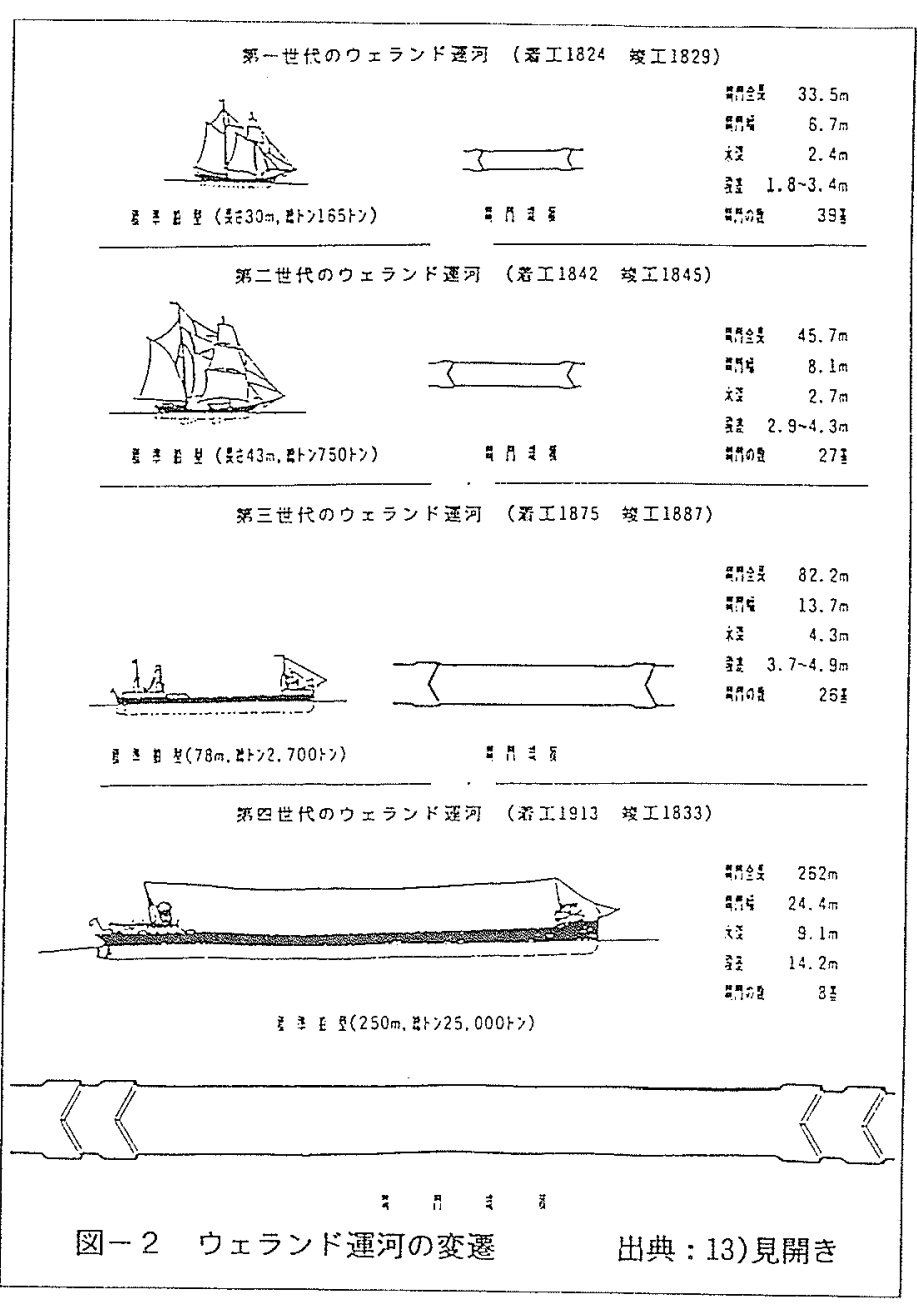

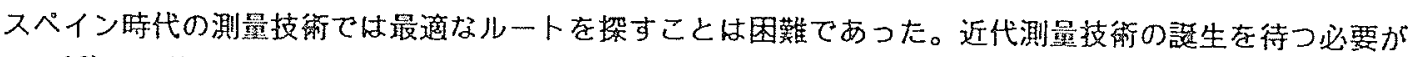
あった ${ }^{19)}$ 。近代的な三角測量は、18世紀前半にフランスで行われ始め、18世紀末にはヨーロッパ各国に普 及した ${ }^{20)}$ 。中米地焕の最初の近代測量調査は、ロイド(J.A. Lloyd)によって1829年、パナマで行われた ${ }^{17) 。 ~}$ その後、ケリー(F.月. Kelley:1851)らによって、手製の高度計、レベルなどを度って、かなり正確な娜量が 行わ执ようになった ${ }^{171211 。}$

1870〜75年にかけて、アメリカ海軍は、当時の最新の科学枝街を駆使し、軍の総力を挙げて調査し、同じ

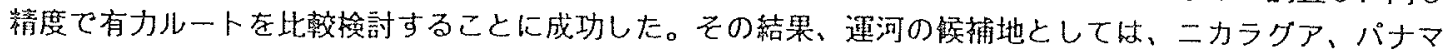

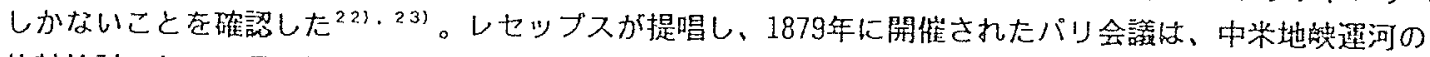

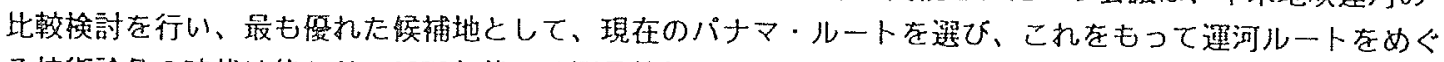

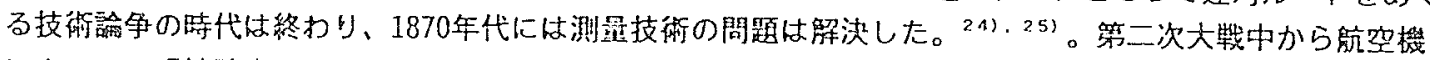
によって、現地踏直をすることなく測量が可能になった。その結果と、16世紀から探検窥や科学者が提案し、

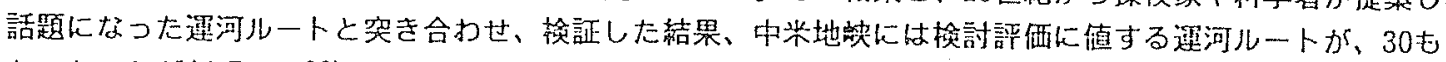
あったことが判明した ${ }^{26)}$ 。 


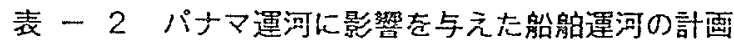

\begin{tabular}{|c|c|c|c|c|c|}
\hline 年 & 提案者 & 場 所 & 特 & 規 & 出 曲 \\
\hline 1829 & 刘卟(0) & ウエラント筙 & 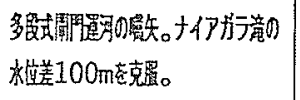 & 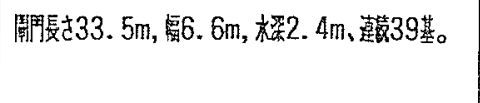 & 13) \\
\hline 1838 & 別ラ○ & H Ț & 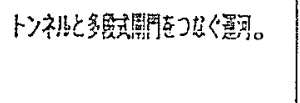 & 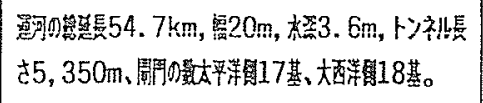 & 16), 17) \\
\hline 1845 & 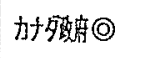 & ウエラント跑 & 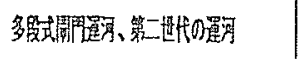 & 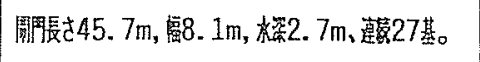 & 13) \\
\hline 1850 & 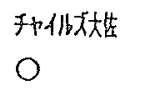 & ニカララグ & 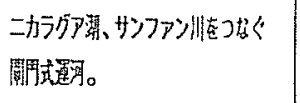 & 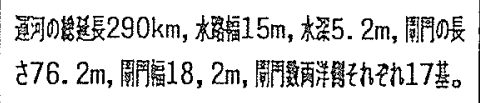 & 17), 27) \\
\hline 1851 & 㓠- & コロンピ & 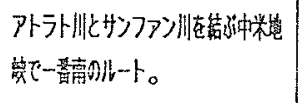 & 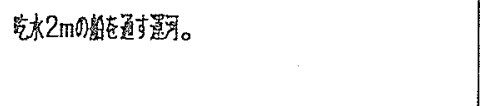 & 17) \\
\hline 1869 & レセップ (O) & $\lambda I \vec{\lambda}$ & 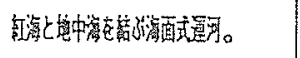 & 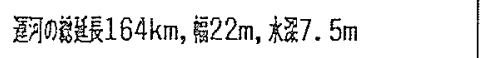 & 28) \\
\hline 1875 & $\begin{array}{l}\text { アメ川旗罩 } \\
\mathrm{O}\end{array}$ & 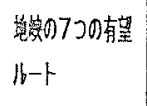 & 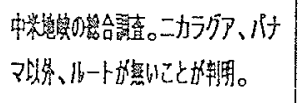 & 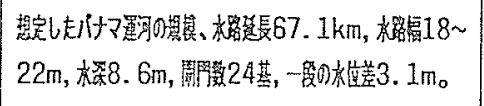 & 17), 22) \\
\hline 1876 & 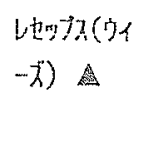 & 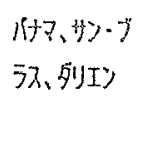 & 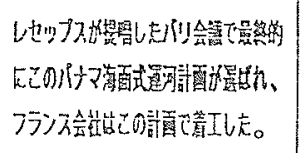 & 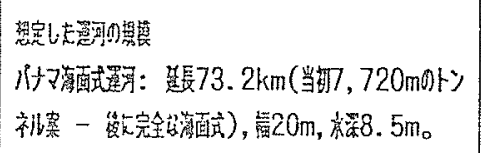 & 23) \\
\hline 1887 & 力十殖庸 ○ & ウエラント算 & 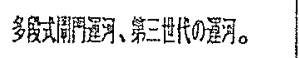 & 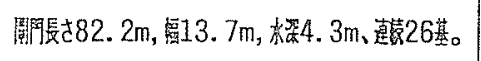 & 13) \\
\hline 1888 & 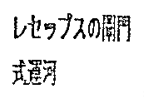 & N+8 & 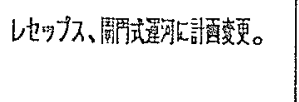 & 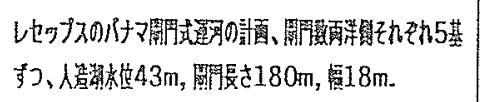 & 29) \\
\hline 1898 & 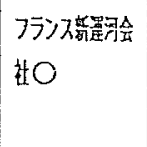 & Itr & 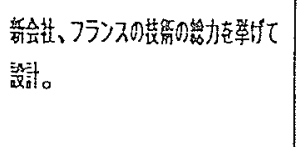 & 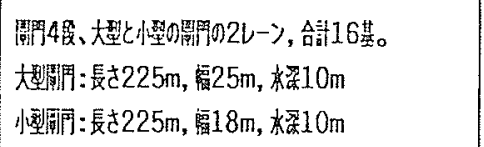 & $30)$ \\
\hline 1901 & ウォー力ー委員会 & ハトマ & 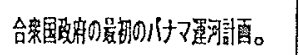 & 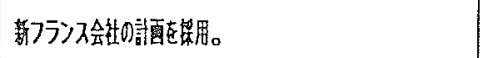 & 31) \\
\hline 1914 & 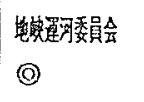 & 琪けマ避 & 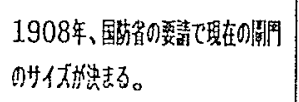 & 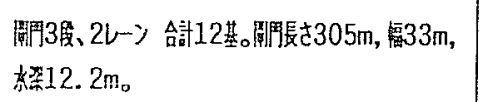 & $32), 33), 34)$ \\
\hline
\end{tabular}

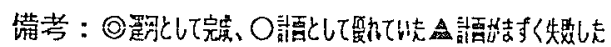


（2）杢製ゲートから鉠銠製ゲートへ

15世紀末に登場した木製のゲー トと石積み閘門の技到以、ヨーロ ッパに運河のネットワークを形成 する役割を果たした。しかし、当 時のヨーロッパの河川運河の閘門 は、上流側と下流側の水位差が2 〜3m、水路水深が $2 \mathrm{~m}$ 、曧3〜10 前後の小さなものであった。

1985年のドナウ(H. Donau)らに よる諭文「低水位差連河から高水 位差運河までの变僄(Des ecluses de faible hauteur aux ouvrages de franchissement des grandes chutes)」によれば、质統的な閘閏 には構造上問題があり、坚験的に

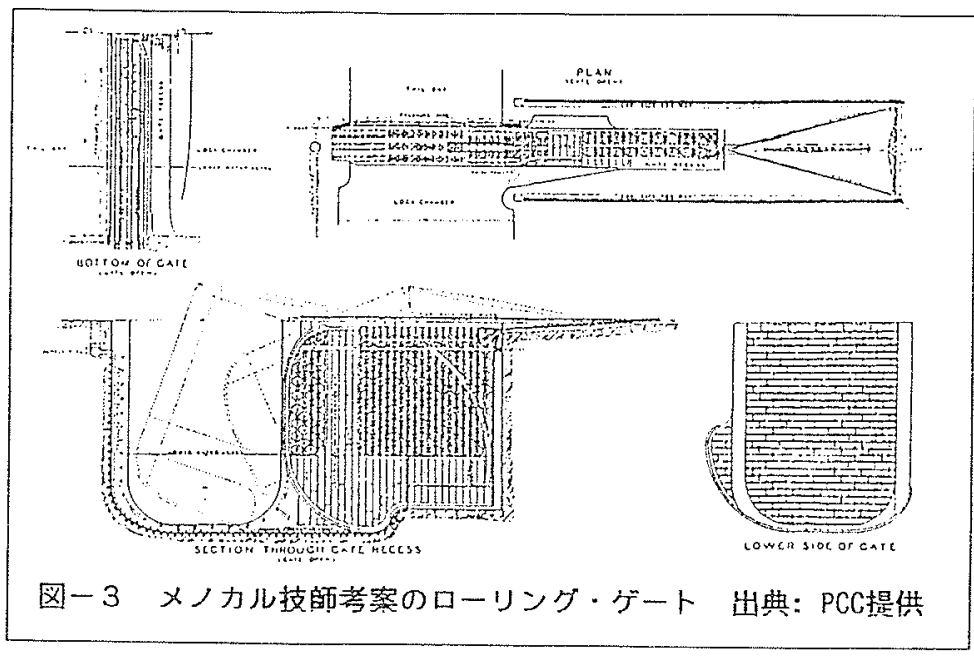

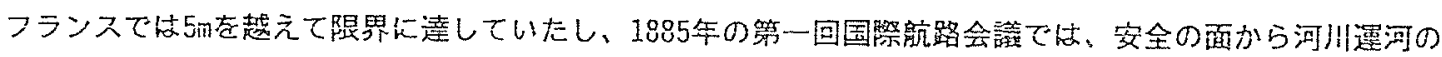
閘開の水位差を5.5m以上にしてはならないという決誴も行なわれたとされている35)。このように1880年代

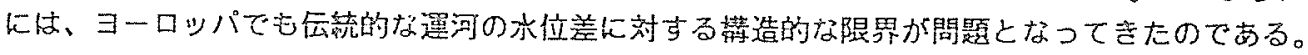

大型昭の運河や急項斜の山岳運河の場合、一つの閘門で大きな水位差を䓔える必要があり、その水压に酎

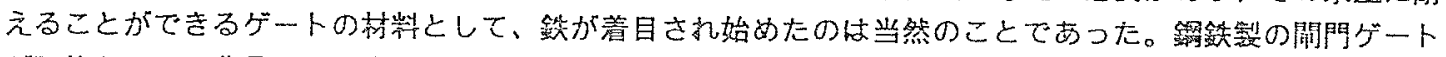
が可能となつた背景には、座業革命による技街革新がある。19世紀初頭には、石炭を利用して鈴鉄定量産す る技街が生まれ、19世紀中頃には、ベッセマー(H. Bessemer:1856)、シーメンス(出.Siemens:1857)らによっ

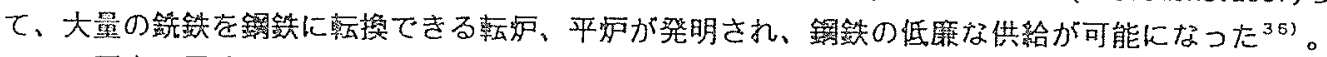

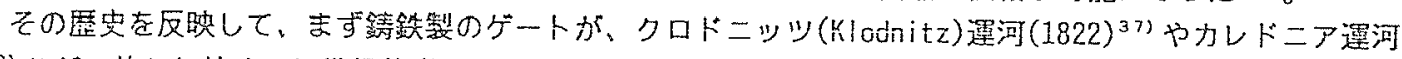
38)などで使われ始め、19世紀後半に出、船舶運河の闆門が銅鉄製になっていつた。アメリカ海簐が1870年

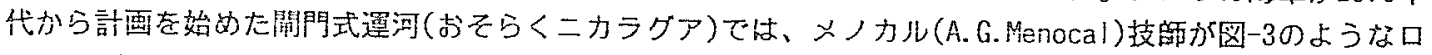
ーリングゲートを提媝しているが、これが中米地蛈渾河計画初めての鉄製ゲートであろう。

著者は、1908年に現パナマ蒾河の計画ができるまでに提案された計画で、パナマ㞄河に影签を与えた6つ の開式運河計画を選ひ、それらの闒門ゲートを本荷で建造したと賏定して、ゲートの厚さを試算(注:前提条

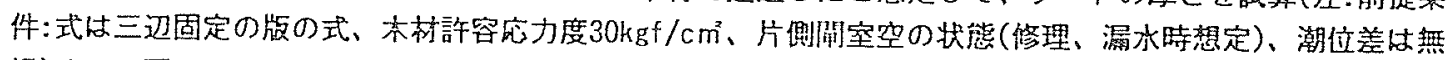
視)すると图-4のような関係が得られた。これによれば、1850年のチャイルズ大佐の計画までは、木树のゲ ートで水压に涌えること杜可能であったが、1870年のアメリカ海軍調查の計画断面から水压が大きくなり、 木材では1mを越える厚さになり、鉄製の䦌門がどうしても必要になってくることが判明した。

1888年、レセップスは、䦌門式運河に設計变更を行い、錀鉄製ゲートの設計を、エッフェル塔を建設した

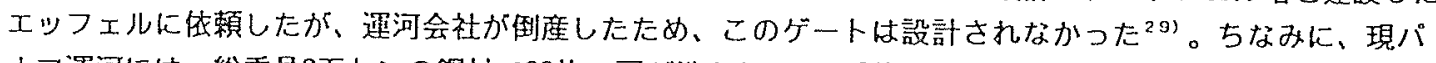

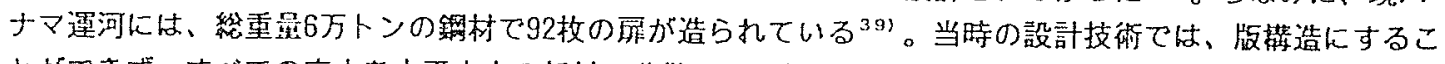
とができず、すべての応力を水平方向の部材に分散させ、蝶畄で受ける設計方法が採られている。

\section{（3）閘門本体の樥造設計と水の注排水方法}

ポルトランド・セメントは、1820年代にイギリスで誔生し、すぐに陸上の满造物に普及しだ0)。パナマ 運河のような海水に浸る巨大な撗造物に使われるようになるには少し時間が掛かった。問題は2つあった。 


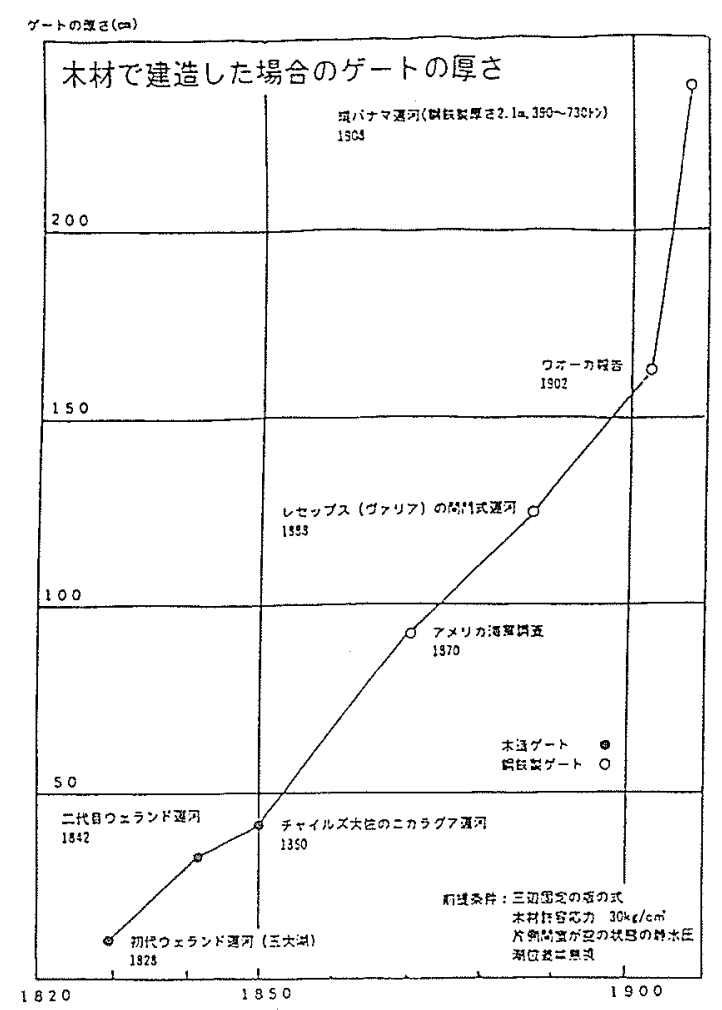

图一 4 一連の中米地蛱運河の計画と 杢淛のゲートの厚さ（試算）
第一はコンクリートの海水劣化問題、第二は重力 式構造物の設計技街であった。第三に、閘門容積が 六きくなったことて、、注排亦(船の待ち)時間をいか に短樎するかという問題が新たに発生した。

第一の海示劣化対策については、当時は石荻によ つて表面を被覆する工法が一般的であった。海水の 影饾を受ける本格的な梅造物は、1847年のイギリス のドーヴァー港のアドミラル・ピアーが敬失であっ たが、その時、湖間带部分のコンクリートを御影石 で被覆する対策が採られ、その後、この工法が普及 した ${ }^{41)}$ 。1904年のパナマ運河のプロトタイプでも 図-5(中央)に示すように、表面を衔影石で被覆する 工法が提案された ${ }^{421 。}$

しかし、1908年の現パナマ運河の最終案の計画で は、この工法は提案されなかった(图-5右端 $)^{43)}$ 。 「パナマ運河委員会」の閘門の管理責任者アルヴァラ ド(C.Alvarado:Marine Dep.)は、「劣化を防ぐため に、閘門のコンクリートについては、当時の最高の 苑工管理を行ったので、77年経っているものの、い まだ、十分な強度を有している」と語っている。

次に、重力式丵造物の築造技衙であるが、アメリ カでは、堤高 $30 \mathrm{~m}(100 \mathrm{ft}$.)を越えるダムの建設は、1 880年代から(Sweetwater Dam:1888)初めて可能とな つた ${ }^{44)}$ 。

パナマ瀷河の閘門やダム(ガッンダムの余亦吐の高さ115ft., 閘門の最大高さ $81 \mathrm{ft}$.$) の建設が始まった1910$ 年代には、堤高90m(300ft.)のダムが可能になっていた

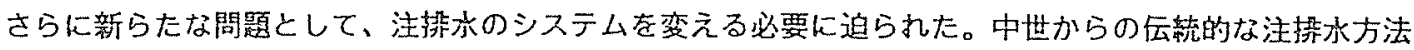
は、図-5の左端のように、ゲートの一部にさらに小さなゲートを設けて、そこから水を移動させていた。し かし、1898年のフランスの新運河会社の計画と1904年のアメリカのプロトタイプからは、水量が大きくなり、 従来の方法ては船が氷流に押され、ゲートに吒きつけられる恐れが出てきた。

新しいアイテアとして、図-5(中央)のように、側壁に設けた孔から注暴水する方法が提案された ${ }^{45}$ 。そ のためには、大量の水を送る大口径のカルバート(注排水管)を壁中に設ける必要があり、その設計が課題と なった。1904年に提出された「ウォーカー(J.G. Halker)委員会報告」の、設計法を以下に考察する ${ }^{46) 。 ~}$

閘門は、サイドウォールとミドルウォールから楧成されており、その構造と作用外力については、底版と の連結を無視した箸純な直立壁で考えている。設計の考えは、次の通りである。

(のコンクリートの許容応力度: $21.1 \mathrm{kgf} / \mathrm{cm}^{3}$ (現在よりかなり小さめ)、破㙼強度は $100 \sim 230 \mathrm{fkg} / \mathrm{cm}^{2}{ }^{47}$ 。

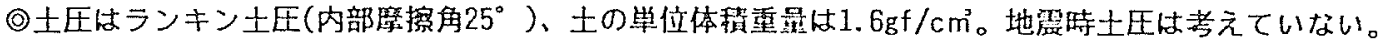
(○サイドウォールについては、图-6の左側に示すように土王、静水圧及び目重の合力が、ミドル・サード ・ソーンの内例になるような壁厚を考えている。

(のサイドウォールの底面の反力の算定においては、コンクリートの引張応力を期待しない計算法を採用し ており、現在の地盤あるい啱盤の応力解析に見られるノーテンション解析か、初步的ではあが、行 われている。 

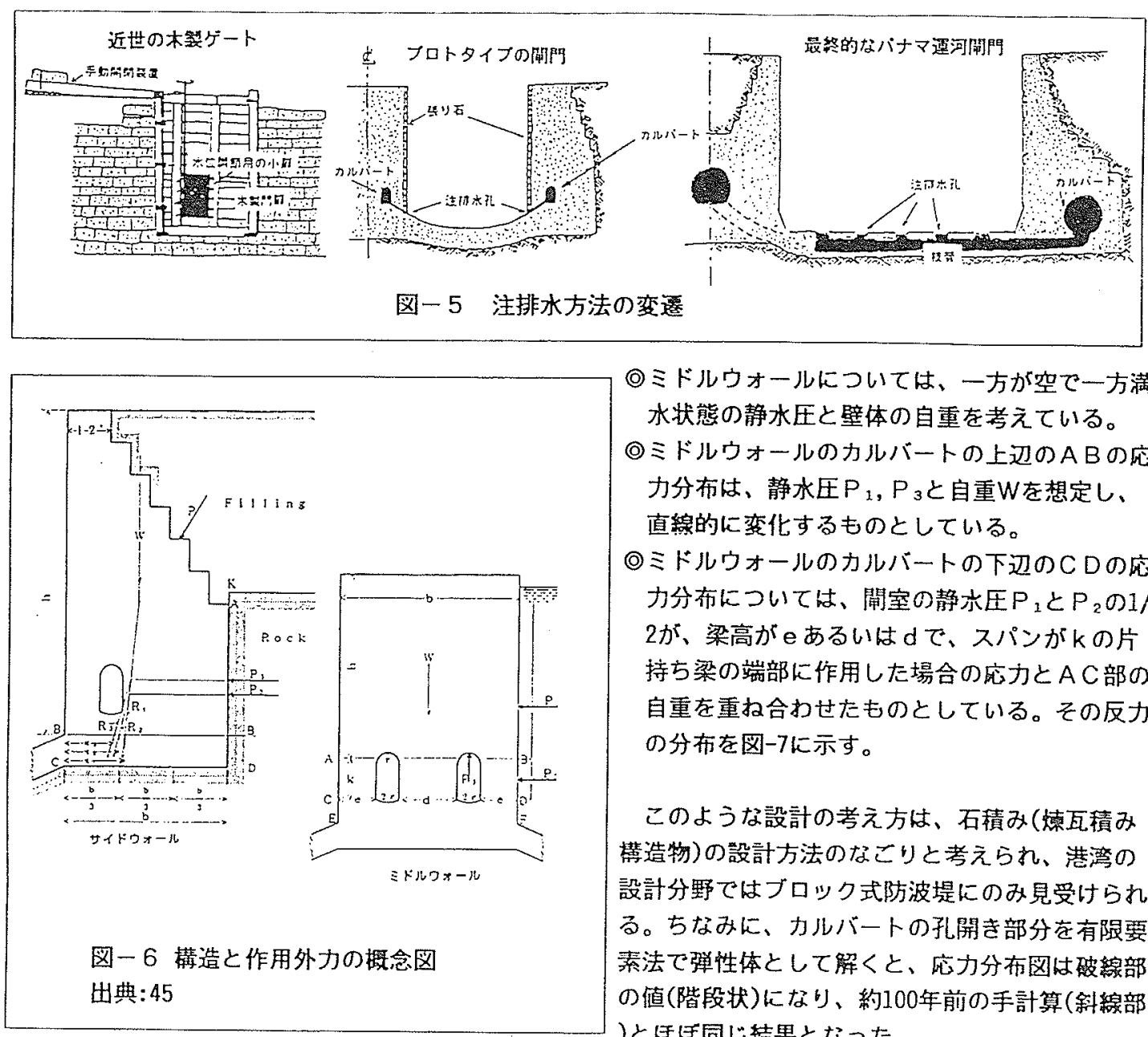

@ミドルウォールについては、一方が空で一方満 水状態の静水压と壁体の自重を考えている。 @ミドルウォールのカルバートの上辺の A B の応 力分布は、静水圧 $P_{1}, P_{3}$ と自重Wを想定し、 直線的に变化するものとしている。 ○ミドルウォールのカルバートの下辺のCDの応 カ分布については、關室の静亦压 $P_{2}$ と $P_{2} の 1 /$ 2が、梁高がeあるいはdで、スパンがkの片 持ち梁の端部に作用した場合の応力と $A C$ 部の 自重を重ね合わせたものとしている。その反力 の分布を図-7に示す。

このような設計の考え方は、石積み(嫃瓦皘み 㝤造物)の設計方法のなこりと考えられ、港潜の 設計分野ではブロック式防波堤にのみ見受けられ る。ちなみに、カルバートの孔開き部分を有险要 系法で弾性体として解くと、応力分布図は破線部 の值(階段状)になり、約100年前の手計算(斜線部 )とほぼ同じ結果となった。

今、計算機の発達によって、我々はこの種の応力解 析をすぐに有限要法で解いているが、このような単 純な解りやすい方法で要素に分割して行うという嗳れ た設計法を先人が採用していたことは筫に値する。

現パナマ運河の開門は、1908年の最終設計て、各閉 門の通過時間を一時問とするように諸元を設定した。 それから逆算して10万トンの水在約8分で注排水出来 るようにしたため、底版の全面から水を注排水するシ ステムになっている (図-5、右側兴照)

この底版から秴排水するシステムは、その後、ヨー ロッパの大型溯門に俥及していつだ8)。

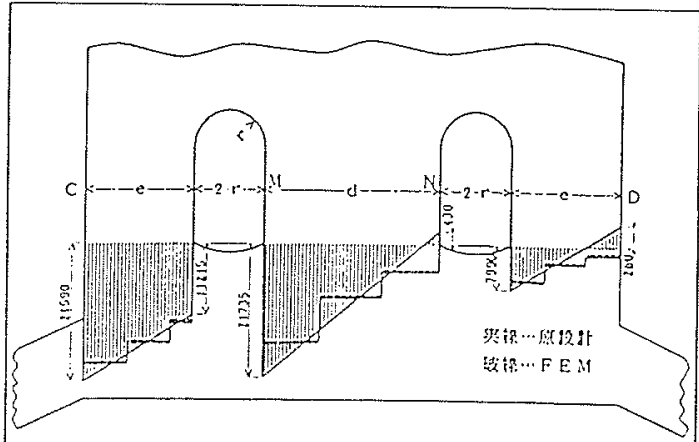

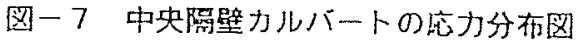
出典：45)Page180と箱者による計算(破䶂部) 
4. 20世紀の遭河計画とその枝䛔的㹎題

運河の規模は、閘門式、海面式運河を問わず、通航船舶の船型と交通量の関係で決まる。基本的な片側1

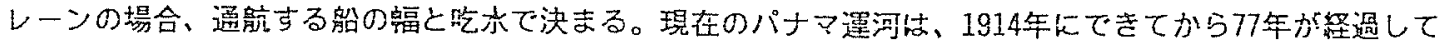
いるが、その間、戦艠、空母、タンカーなど大きな船を通そうとする試みが、表-3のように数多く行われて きた。その詿みは大きくニつに分けられる。第一は、現在の本路に新しい闃門奆增設しようとする考えで、 第二は、新しい別の水路、もしくは、現在の水路の側に海面式運河を造ろうとする考えである。閭門式運河

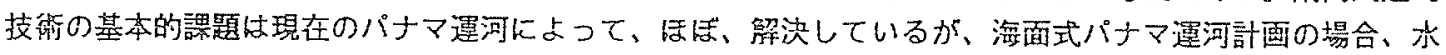
路断面が大きくなってきたことによって、跆大な土量が生ずるという新らしい問題に面面している。

表 一 3 20世紀の主なパナマ運河計画

\begin{tabular}{|c|c|c|c|c|c|}
\hline 年 & 計画名 & 場 所 & 特 & 模 & 出 \\
\hline 1931 & 第二周网社面 & 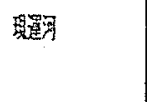 & 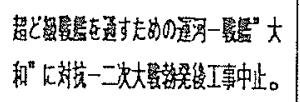 & 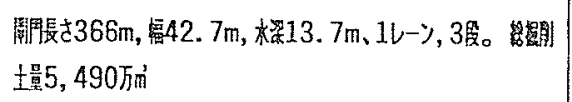 & 49), 50) \\
\hline 1947 & 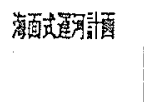 & 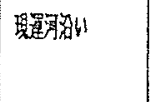 & 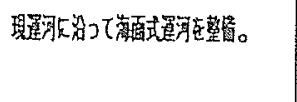 & 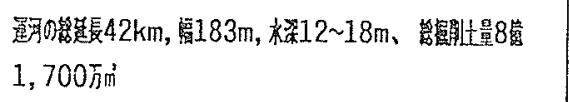 & 51) \\
\hline 1947 & 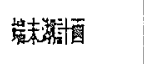 & 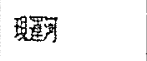 & 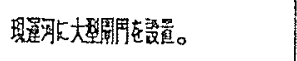 & 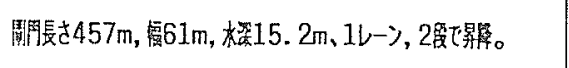 & 51) \\
\hline 1970 & $\begin{array}{l}\text { ルトト10靠配 } \\
\text { 鄫河 }\end{array}$ & 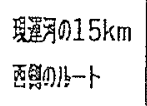 & 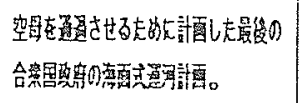 & 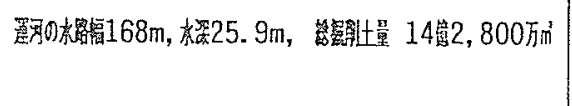 & 52) \\
\hline 1970 & 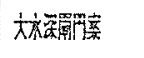 & 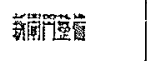 & 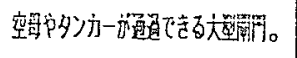 & 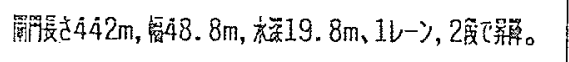 & 52) \\
\hline 1979 & 来婜 & 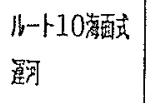 & 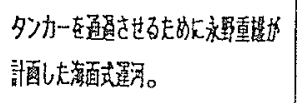 & 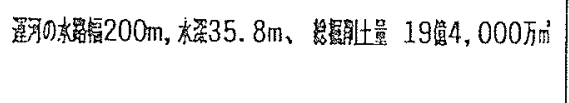 & 53) \\
\hline 1981 & 口伍・无喓 & 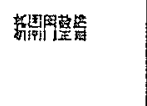 & 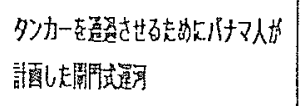 & 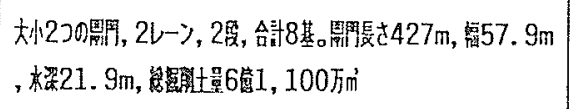 & 54) \\
\hline 1982 & রル片一ラ案 & 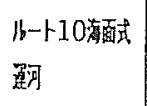 & 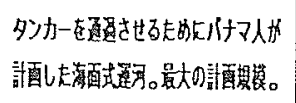 & 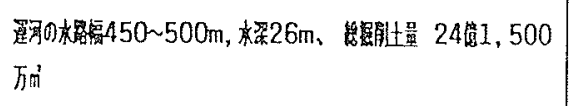 & 55) \\
\hline
\end{tabular}

（1）㞄河の水路断面の变要

近世のヨーロッパの内陸河川運河計画から最近の新しいパナマ荤河計画までの主な運河の横断面の变䒱を 示し(图-8)、それら遇河の断面決定法の歴史的な变禫を以下に考察した。

19世紀に生まれた船舶運河ては、船躳の大型化に対応した断面決定方法が次々と編出されてきた。それ以

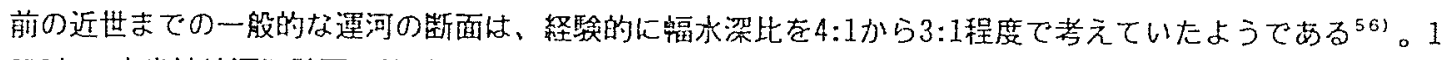
879年に中米地蛱運河計画の检討を行ったパリ会議では、すべての運河案に対して、当時のスエズ連河のサ 


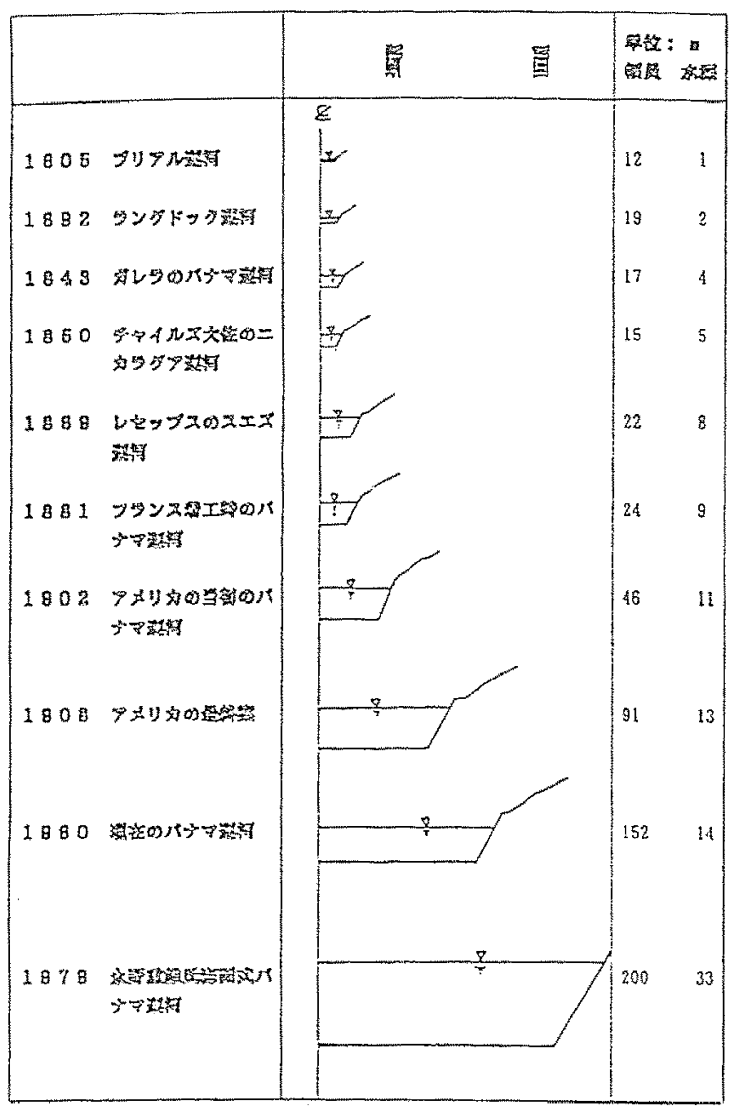

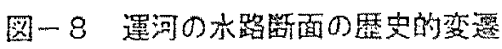

イメ゙を缡男し、比較馀討を行つている

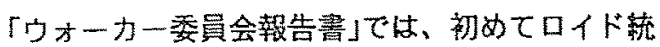
詰を利用して、現パナマ量河のプロトタイプの亦路 と關門サイズを決定した。曲緬部では、曲率に応じ て办路福買を垃大することを行めて行った 初の現パナマ運河計画の水路輻は92mであったが、

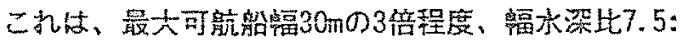
1程度と考えていたらしい"34。一方、現パナマ邁河 の關門サイズは、1904から1900年にかけて地蜼㖶 河委員会」で再㮔討されたが、最終的には国防省か

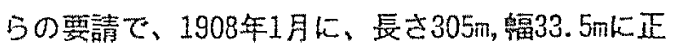
式に济まった

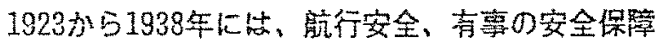
を考虑して、水路の崩落地带、实搡曲鼣部を福150m

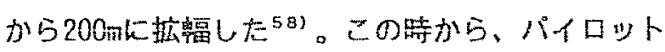
の意見を勢考にして、拡福計画か進められ始めた。

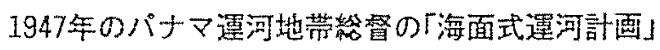

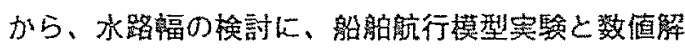

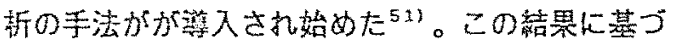

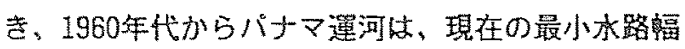

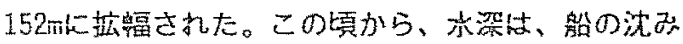
込み(Squat)とセイシュ(Surge Seiche effect)を考

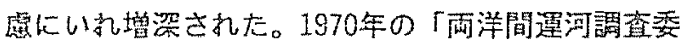

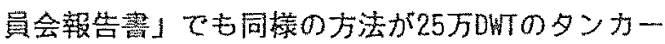

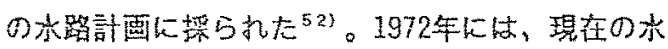

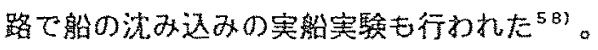

最近のクレブラ・カットの苰锚尌画で、塻型实 驗と計算機の数值シミュレーション、パイロットの

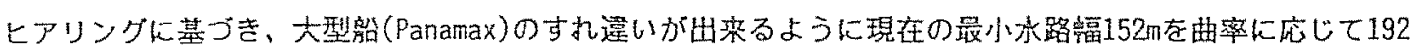
から229mに㹡䒇する計画が出されている59?。

以上が、パナマ運河を中心とした19世紀からの的船運河の断面を設定する考え方の变遥であるか、不確实 な部分は、どのような船型を想定するかという点である。理諭的には搏来の潜在需要を想定したときの便益 とコストの差が最大になる所で最適の船型が決まるが、蛰長期を予测するというところに限界がある。

\section{（2）称的と霜河サイズの变遥}

19世紀初頭からの一連の中米地的運河計画の水路の断面とそれぞれの時代の船の断面に関して、以下のよ うな分析を行った。すなわち、それそれの時代における個々の運河計画の水路断面と切期の视船から蒸気船、 軍艦、空母、数十万トンのタンカーまての、その時代の最大船の船型断面のデーターベースを作成し611，62)

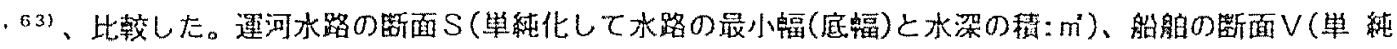

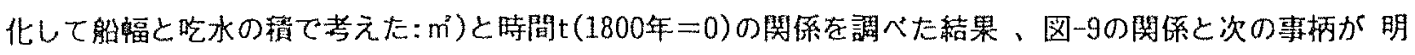
らかになった。

a）19世紀以降の軍河の計画水路断面(底福 $\times$ 水深)の增大頋向は、船船断面(輻 $\times$ 吃水)の大型化頋向と合 


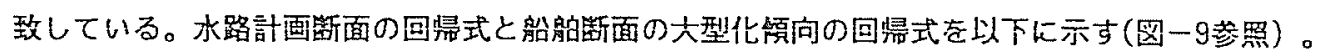
運河断面の大型化(1843 1982): $\quad \log S=0.0146 t+1.12 \quad(r=0.986)$ 全船船の大型北頃向 $(1831 \sim 1972) ： \log V=0.0106 t+1.11 \quad(r=0.939)$

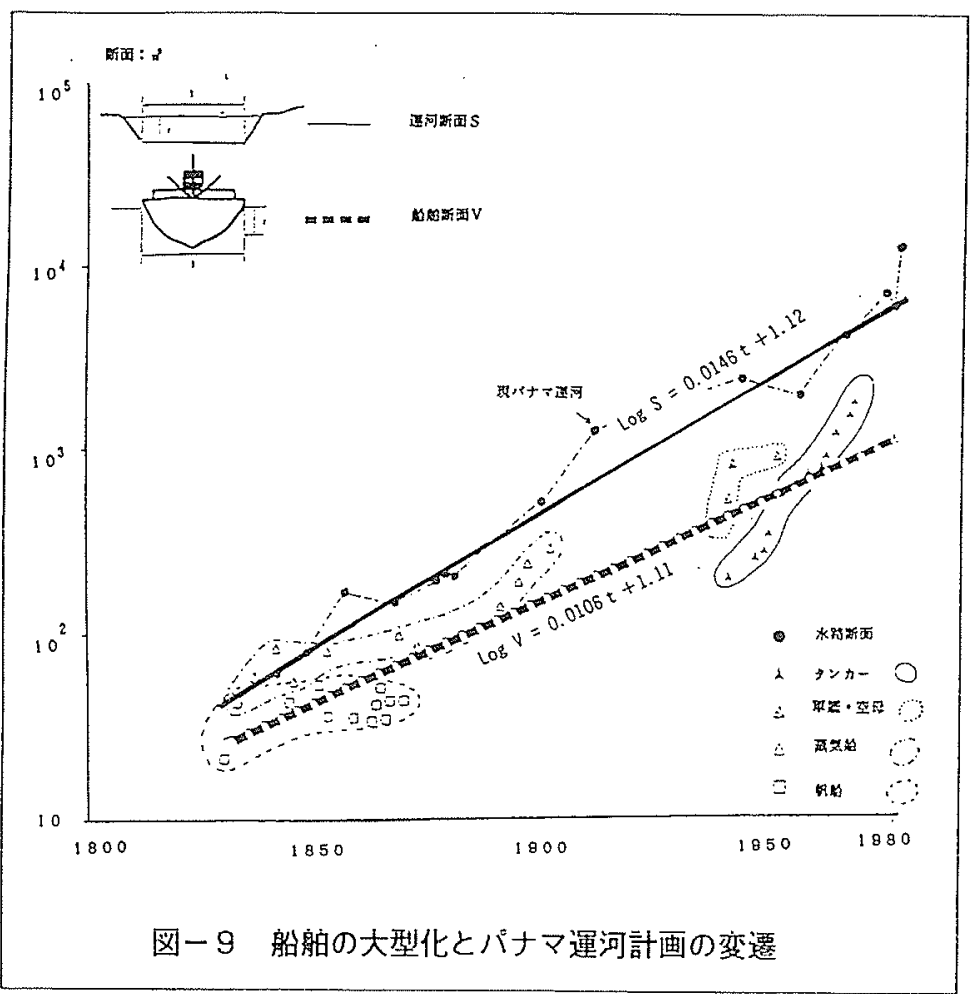

前提：(1) 当該年に建造された最 も大きな船のデータを 入れた。

(2) 帆船のテータから吃水 を求めることができな かったのて、、吃水は帆 船の径梁)の $1 / 2$ と仮定 した。

b）帆船の時代は1870年代で終わ り、スエズ運河では、当初か ら、当時発展途上にあった蒸 気船に焦点をあてて通河計画 が作られた。中米地融運河に 関する一連の連河計画も、図 -9を見ると、蒸気船に照準 を当てて進めらてきたと推諭 出来る。19世紀半ばに全盛時 代を迎えた的船は、中米地畹 運河に影響を与えるところと はならなかった。

c）1914年完成当時のパナマ運河 の水路断面标、計画断面回帰

式よりかなり上方に北離してお り、当時としては大きいサイズ の運河を考えていたことが読み 取九る。

d）第二次大戦後の計画について見 ると、「両洋間運河調盗委員会 報告瑟」以降は、スーパー・夕 ンカーのサイスに合わせて運河 計画も犬きくなつている。同報 告墨を含めてそれ以前の計画は 軍船、空母在主眼においた計画 でらた。それ以降の1979年の 永野レポートの的、ベルガーラ -(D. Vergara)レポート55) の 水路断面の大型化領问过、タン カーの大型化の頖问と一致して いる。

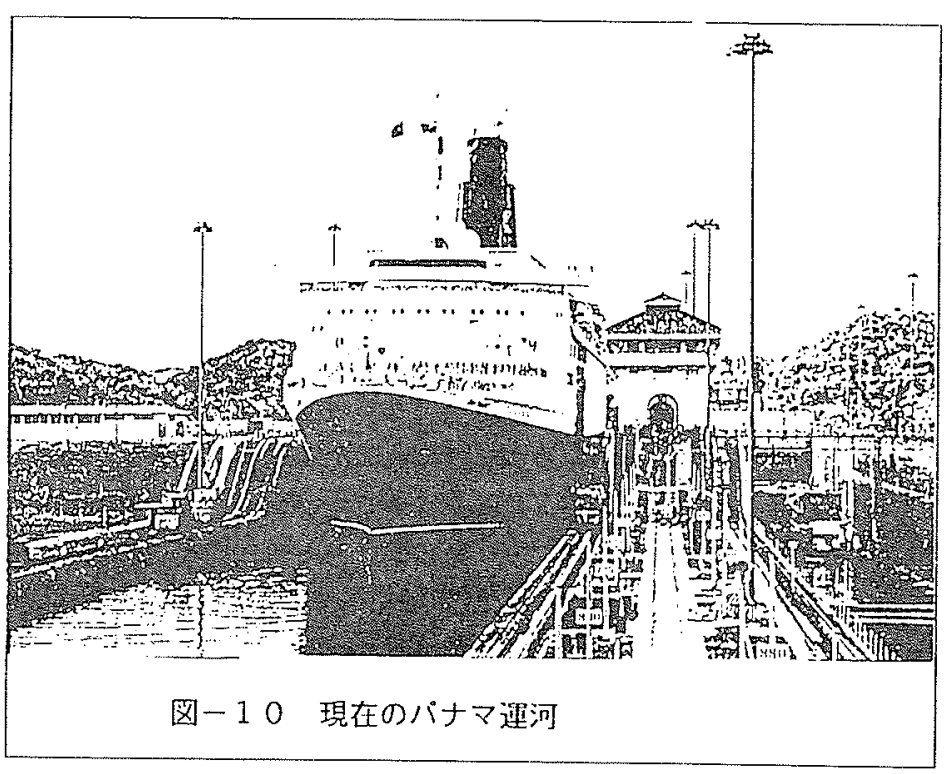


むわりに

以上、パナマ運河を中心に閘門式運河の歴史とその技街発展過程を概観したが、最後にその結諭をまとめ、 著者の見解を述べる。

a)19世紀初頭までは技街力の不足から中米地峡に運河はできなかった。

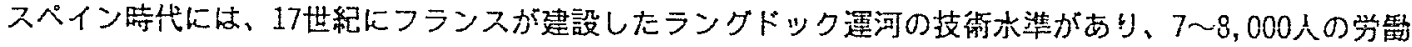
力が得られれば、当時の標準的な低水位差の河川運河は可能であった。しかし、前述したように、中米地

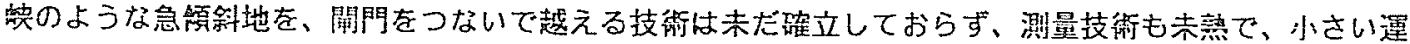
河といえども不可能であったと考えられる。

b)19世紀半ばには、小さな㖶河であれば技街的に可能になった。

19世紀前半には、連続して閘門をつなぐシステムで大きな水位差を克服できるようになったこと、土木施 工技街も発達したこともあり、小さな船㿟を対象とする閘聞式遣河であれば实現していたと考えられる。

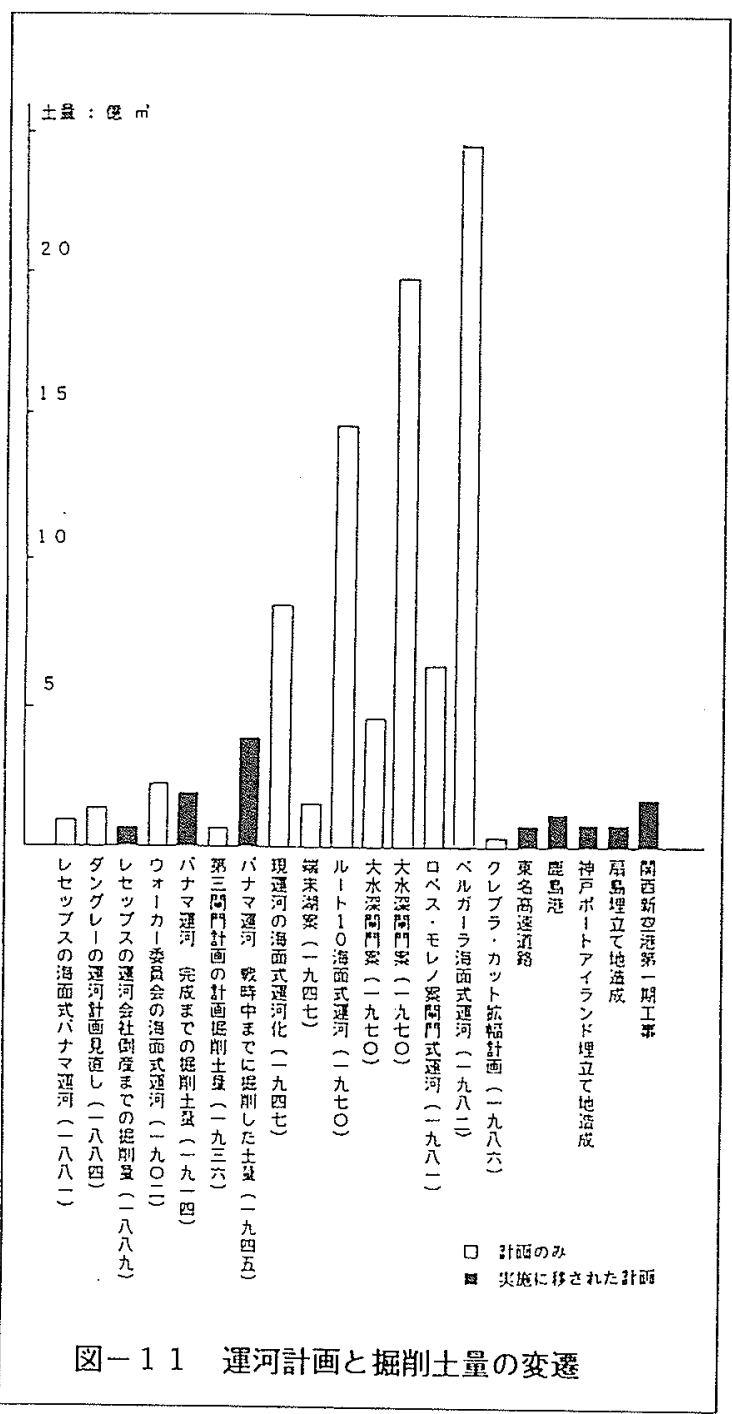

c）レセップスが挑戦を開始した1882年には、高水位 差の閘門式運河は可能になっていた。ダム築造技 街の進歩、ダイナマイトの発明(A. Nobel:1867) もあり、運河建設の技街はそろっていたと考えら れる。彼杖7年間で5,970万 $\mathrm{m}^{3}$ 掘剀しているので， もし、当初の規模の運河(偪24m, 水深8.5m)を、閘 問式で計画してお机ば、1 2万トンの船を通過さ せる小さな運河は完成していたと考えられる。

d)アメリカは当時の先端技術を駆使して閘門式運河 を完成させた。アメリカは、1914年に現在の閘門 式運河 (全長 $80 \mathrm{~km}$, 水路蝠 $92 \mathrm{~m}$, 水深 $12.2 \mathrm{~m}$, 閘門数 12 基)を完成させた。詳しくは3笁を参照していただ きたいが、技術発展の関係から、現パナマ運河の ような大さな閐聞式運河はこの時期にようやく可 能になったとみるべきである。

e)船型の大型化と土量の限界

その後のパナマ運河計画については、对象船舶が 大型化したことによって、表-3のように、より大 きな水路と閙門を持つ運河が要求されてきた。ち なみに、その土量を考えてみると、1945年までに パナマ運河で掘削した土量3檍7,000万 $\mathrm{m}^{341}$. 58) は、日本の高度経済成長時代に实施した東名高速 道路の掘削 $\left(6,600\right.$ 万 $\left.\mathrm{m}^{3}\right)$ 、扇島の埋立 $\tau(8,000$ 万 $\mathrm{m})$ 、神戸ポート・アイランドの埋立て $(8,000$ 万

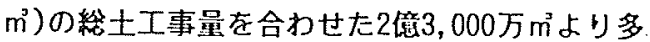

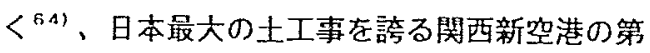
一期工事の埋立て $\left(1\right.$ 億6、400万 $\left.\mathrm{m}^{\circ}\right)$ より多い。さら に、图-11に示すように、現在、徂上に载ってい る海面式運河のどの案も10檍 $\mathrm{m}^{3}$ 越えようとする 莫大な土量である。

「両洋間連河調查委員会」では、㽙大な土量の掘削 


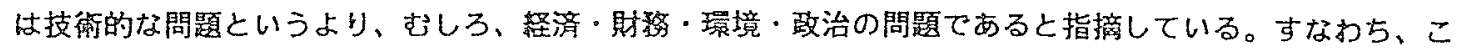

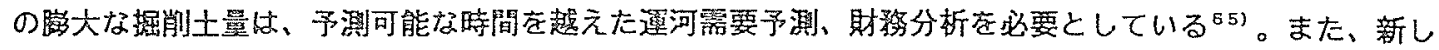
い㖶河ルートは、住民の立退を必要とし、広大な土搭て場を牧場や沿岸漁場に求めなけ机ばならず、これら

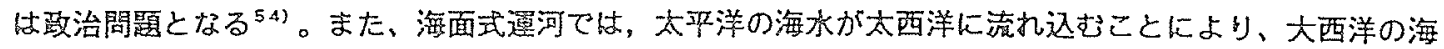

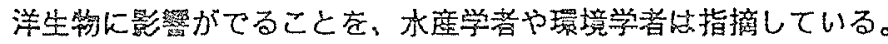

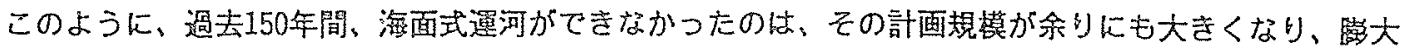

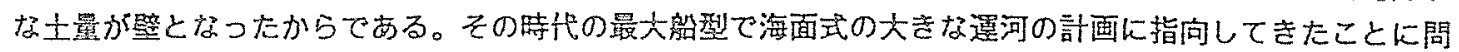

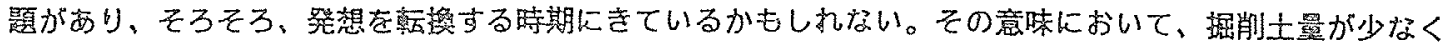

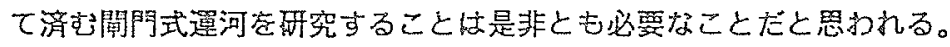

また、近年の我が园の入都市にお壮る物資翰送が、昭和30年代以降、もっぱら自動車翰送に统存してきた

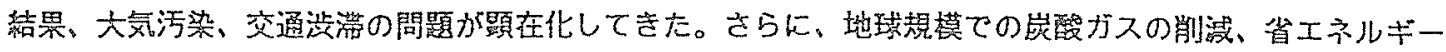
も叫ばれている。歴史的な視野で見れぼ、かっての江戸、大限などの都市の繁栄を支えた低公恝型翰送の内

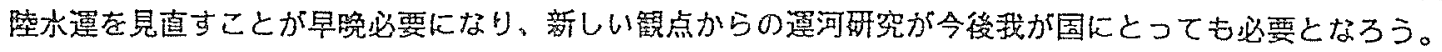

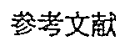

1) G.H. Goethals: Introduction, TTransaction of the International Engineering Congress 1915 the Panama Canal IJ, ASCR, S.R. California, pp.1 5, Sept. 20-25, 1915

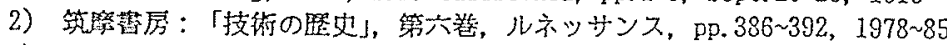

3) Americana Corporation: TThe Encyclopedia Americana」, Vol.5, 「Canals 」, pp. 517 523

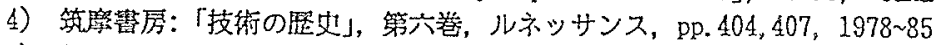

5）長野正孝：世界港淡発展史，「港湾了，日本港济協会，pp.64，April 1988

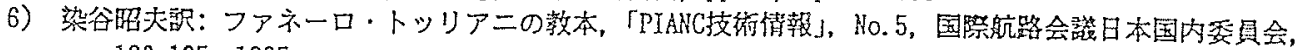
pp.120 135, 1985

7) Donau H, Schroder D. and Tzschucke H.P.: Des ecluses de faible hauteur aux ouvrages de franchissement des grandes chutes, Centenary of the Permanent International Association of Navigation Congresses 1885-1985」, PIANC, pp.173 174, 1985 (H. ドナウ, D.シュレーダー, H.P.トシ

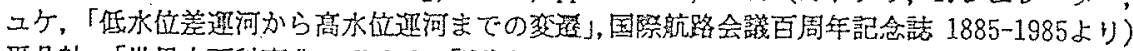

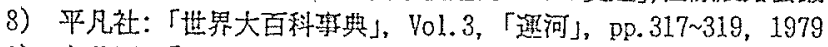

9）永井厚：「トーマス・テルフォードとカレドニア邀河」，二チマ, Sept.1991

10）平凡社：「世界大百科害與」，Vol.27，「フランス」, pp.96, 1979

11) Americana Corporation: TThe Encyclopedia Americana」, Vol.12, 「Germany」, pp. 561

12) Gota Canal Steamship Company: 1992 The Gota Canal

13) Cowan P.J.: 「The Helland Ship Canal between Lake Ontario and Lake Brie」, Engineering News Record, 見開きとPP. 1 4, 1913〜32

14) Forbes-Lindsay C.H.: 「Panana The Isthmus and Canal」. The John C. Winston Co., Philadelphia pp. 295 359, 1906

15）永井 厚:「トーマス・テルフォードの生涯・その叙述的物語」, 二チマ, Sept. 1985

16) Mack G.: The Land Divided - A History of the Panama Canal and other Isthmian Project」, OCTAGON B00K, New York, pp.127 130, 1974

17) Sullivan J.T.: FReport Historical and Technical Information relating to the Problem of International Communication by way of the American Isthmus」, Hashington Government Printing Office, pp.65〜76, 1883

18）永井原：「トーマス・テルフォードとカレドニア巡河」,ニチマ, pp.103〜138, Sept.1991

19) 艮野正孝(Hasataka NAGANO): The Historical Development Planning for the Pamama Lock Canal, Proc. of JSCE., No. 131/IV- 15, pp.135 136, July 1991

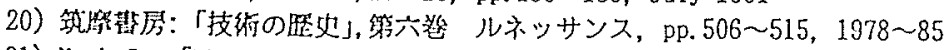

21) Mack G.: TThe Land Divided - A History of the Panama Canal and other Isthmian Project], OCTAGON BOOK, New York, pp. 65 71, 1974

22) Ammen D.: FInter-Oceanic Ship Canal Question J, 1880 
23) Sullivan J.T.: TReport Historical and Technical Information relating to the Problem of International Communication by way of the American Isthmus, Hashington Government Printing Office, pp.118 133, 1883

24) Hack G.: TThe Land Divided - A History of the Panama Canal and other Isthmian Project」, OCTAGON BOOK, Her York, pp. 287 297, 1974

25) McCullough D.: FThe Path between the Seas」, A Touchs Book, Simon and Schuster, N.Y. pp. 70 100, 1977

26) Stratton J.H.: The Puture and the Panama Canal, 「Panama Canal The Sea-Level Canal Project,, A Symposium, ASCB., pp. 452,1948

27) Mack G.: TThe Land Divided - A History of the Panama Canal and other Isthmian ProjectJ, OCTAGON BOOK, Hew York, pp. 188 189, 1974

28）木内政鋭, 日下正: スエス僬河新情, 土木学会誌 47 巻, April 1972

29). Mack G.: The Land Divided - A History of the Panama Canal and other Isthmian Project」, OCTAGON BOOK, Hew York, pp. 330 333 1974

30) Hack G.: TThe Land Divided - A History of the Panama Canal and other Isthmian Project, pp. 410 411, OCTAGON BOOK, New York, 1974

31) Halker J.G. and other commissioners: RReport of the Isthrian Canal Commission 1899-1901」, Government Printing Office, pp. 44 48, 1904

32) Hodges H. R.: General Design of the Locks, Dams, and Regulating Works of the Panama Canal, Transactions of the International Engineering Congress, the Panama Canal II J. S.F. California, pp. 1 5, 1915

33）筜山士：「ぱなま遇河の話」。吉田的剧所, Hay 1939

34) G. H. Goethals: Introduction, TTransaction of the International Engineering Congress 1915 the Panama Canal IJ, ASCE, S.P. California, pp. 28, 29, Sept.20-25, 1915

35) Donau H., Schroder D. and Tzschucke H.P.: Des ecluses de faible hauteur aux ouvrages de franchissement des grandes chutes, TCentenary of the Permanent International Association of Navigation Congresses 1885-1985」, PIANC、 pp.176, 180, 1985

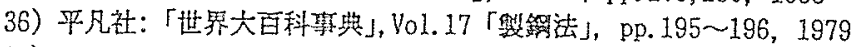

37) Donau H., Schroder D. and Tzschucke H.P.: Des ecluses de faible hauteur aux ouvrages de franchissement des grandes chutes, Centenary of the Permanent International Association of Navigation Congresses 1885-1985」, PIANC, pp.175, 1985

38）永非：「トーマス・テルフォードとカレドニア連河」，二チマ, pp.112〜115, Sept.1991

39) Hodges H.P.: General Design of the Locks, Dams, and Regulating Works of the Panama Canal, TTransactions of the International Engineering Congress, the Panama CanalII], S. F. California, pp. 5,1915

40）日本ボルトランドセメント同策界：「替のコンクリート」, 生田闲刷所, pp. 3, Oct. 1936

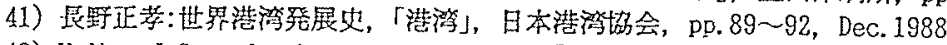

42) Halker J.G. and other comaissioners: RReport of the Isthmian Canal Commission 1899-1901」, . Government Printing Office, pp.89 92, Plate 24, 1904

43) Cornish L.D.: Design of the Lock Walls and Valves of the Panama Canal, ITransactions of the International Engineering Congress, the Panama Canal If, S. R. California, pp. 66, 1915

44) Americana Corporation: TThe Encyclopedia Americana , Vol.8, 「Dams J, pp. 438

45) Hodges H. P.: General Design of the Locks, Dams, and Regulating Korks of the Panama Canal, TTransactions of the International Engineering Congress, the Panama Canal II J. S. F. Cal ifornia, pp. 9 14, 1915

46) Walker J.G. and other comnissioners: rReport of the Isthmian Canal Commission 1899-1901J, Government Printing Office, pp.178 198, 1904

47) Cornish L. D.: Design of the Lock Halls and Valves of the Panama Canal, TTransactions of the International Engineering Congress, the Panama Canal II 」, S. P. California, pp.65, 1915

48) PIANC: TFinal Report of the International Commission for the Study of Locks J, Supplement Bulletin No. 55

49) Edgerton G. B.: 「The Third Lock Project, J, January 1941

50) ICC: TThe Third Set of Locks」, Panama Canal Twenty-fifth Aniversary Book, August 1911 
51) 79th U.S. Congress: RReport of the Governor of the Panama CanalJ, Under Public Law 280,

52) Anderson R. B. and other commissioners: IInteroceanic Canal Studies 1970」, 726 Jackson Place N.H., Hashington D.C. 20506 , Dec. 1970

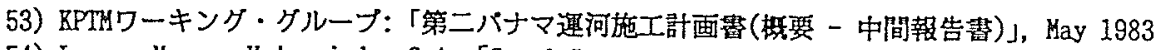

54) Lopez, Horeno $Y$ Asociados S.A.: [Canal Interoceanico La Alternatives]

55) D. Vergara S. : [Bl CANAL A NIEVELJ

56) Halker J.G. and other commissioners: TReport of the Isthmian Canal Commission 1899-1901J, Government Printing Office, pp. 44 48, pp. 98, 1904

57) Hodges H. P.: General Design of the Locks, Dams, and Regulating Horks of the Panama Canal, 「Transactions of the International Engineering Congress, the Panama Canal II J, S.F. California, pp. 2, 1915

58) ICC(PCC): 「Isthmian(Panama) Canal Cormission Annual Report], 1915 1988

59) PCC:「Gaillard Cut Widening Feasibility Study -Environmental Report」, Vol.1 and 2,1987

60) Kc. Nally Rand : TSailing Shipj

61) Lausanne Edita : TThe Great Age of Sail」, 1967

62) Hoor J.: TJane's Righting Ship 1987-1988 J, pp. 719 728

63）堀井修身ほか：「原油タンカーバース調查」,港研資料 No. 201

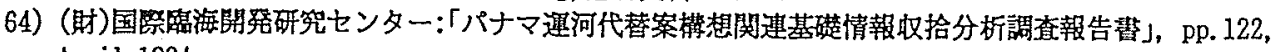
April 1984

65) Anderson R.B. and other commissioners: Interoceanic Canal Studies 1970」, 726 Jackson Place N.H., Hashington D.C. 20506, pp. 105 108, Dec. 1970 